OnLine Journal of Biological Sciences 12 (2): 80-88, 2012

ISSN 1608-4217

(C) 2012 S. RayChaudhuri et al., This open access article is distributed under a Creative Commons Attribution (CC-BY) 3.0 license

\title{
East Kolkata Wetland: A Multifunctional Niche of International Importance
}

\author{
${ }^{1}$ S. Ray Chaudhuri, ${ }^{2}$ I. Mukherjee, ${ }^{3}$ D. Ghosh and ${ }^{4}$ A.R. Thakur \\ ${ }^{1}$ Department of Biotechnology, School of Biotechnology and Biological Sciences, \\ ${ }^{2}$ Department of Natural Sciences, School of Management and Sciences, \\ West Bengal University of Technology, BF-142, \\ Sector 1, Salt Lake, Kolkata-700064, West Bengal, India \\ ${ }^{3}$ Regional Chair (South Asia), Commission on Ecosystem Management, \\ IUCN, Flat 3A, 370/1L NSC Bose Road, Kolkata-700047, West Bengal, India \\ ${ }^{4}$ RCM BioSolutions Private Limited, A-101, Green Woods Premium, \\ Kaikhali, Shibtala, Kolkata-700136, West Bengal, India
}

\begin{abstract}
Problem statement: In the megacity Kolkata, the need for space to accomodate the ever increasing population is increasing day by day. As a result the encoarchment of the large wetland on the eastern frindge of the city is increasing and so is the threat of its loosing the status of Ramsar Status. Approach: Proper documentation of the existing traditional practice with sound scientific basis and the direct as well as indirect benefit that the city receives as a result of its existance could be an approach towards its conservation. Results: East Kolkata Wetland (EKW) is a unique example of a wetland ecosystem involved in both resource recovery and environmental protection and in the process providing a stable urban fringe to an expanding metropolis. It ensures economic benefit and employment generation because of resource recovery activities based on utilization of the city's sewage. It acts as a sink for city sewage and garbage, even at times a little flow of industrial effluents with toxic heavy metals as well as hazardous contaminants like sulphate and nitrate to name a few. The purification process operating there depends to a large extent on the activity of the diverse microbial population using liberal sunshine. On trying to understand the microbial flora, a rich diversity of the bacterial domain was revealed with immense potential for commercial application. The extracellular enzymes from microbial origin of EKW were used for detergent formulation, dehairing of hide at neutral $\mathrm{pH}$, silver recovery from exposed X-ray films and so on. The microbes themselves could entrap metals inside them as nanoparticles, remove sulphate from solution and prevent nitrate mediated eutrophication. The soluble waste from the megacity goes through various rounds of purification in the waste water fisheries, called Bheri in local parlance before being used for agriculture. This in turn results in fish production and purification of the waste water up to $99 \%$ in terms of faecal coliform count and to a large extent for other parameters. The metal content in the muscles of the surface feeder and bottom feeder fishes were comparable to that of the same variety from rain water fed ponds, indicating safe use of the waste water. The agriculture using waste water mostly produces paddy and vegetables. The green leafy vegetables produced from EKW when compared with same variety from non-EKW were found to be healthy without any additional unwanted metal accumulation. The entire resource recovery process was relatively safe, ecofriendly as well as economical. Conclusion/Recommendations: Thus EKW purifies the waste of a large part of the city, generates edible resources, provides employment, houses diverse flora and fauna and also harbours a rich repertoire of microbes with immense potential for application. The objective of the present review is to emphasize the need of its conservation and also intensify the research on the microbial diversity in these wetlands.
\end{abstract}

Key words: East Kolkata wetland, bioremediation, microbes, sulphate reducing bacteria, nitrate reducing bacteria, phytoplankton, integrated resource recovery

Corresponding Author: Shaon RayChaudhuri, Department of Biotechnology, School of Biotechnology and Biological Sciences, West Bengal University of Technology, BF-142, Sector 1, Salt Lake, Kolkata-700064,

West Bengal, India 


\section{INTRODUCTION}

In addition to its wise use uniqueness, East Kolkata Wetland (EKW), earlier known as East Calcutta Wetland $\left(22^{\circ} 27^{\prime} \mathrm{N} 88^{\circ} 27^{\prime} \mathrm{E}\right)$ is also rich in biodiversity as it contains about 104 plant species, about 20 important mammalian species, various threatened reptiles, more than 40 bird species including both local and migratory types, 52 endemic varieties of fishes of which 34 are threatened and a huge number of diverse microbial populations including those, playing active roles in the wastewater treatment.

This vast area $(\mathrm{EKW})$ includes intertidal marshes, salt meadows with significant waste water treatment areas like settling ponds (locally known as Jheels and Bheries), Sewage Canals (RSC) and farms, oxidation basins, dumping ground, green zone and cultivable lands (Ghosh, 1998). EKW was designated as 'wetland of international importance' under 'Ramsar convention' on $19^{\text {th }}$ August, 2002 and as 'Ramsar site' in November, 2002 (Ghosh, 1998; Furedy and Ghosh, 1984). Including $\mathrm{ECW}$, total 19 wetlands in India were designated as Ramsar site till 2002 (http://en.wikipedia.org/wiki/List_of_Ramsar_Sites_in_ India). Later, on $8^{\text {th }}$ November (World Wetlands Day), 2005, six new wetlands were designated, bringing the total number of Ramsar sites in India to 25 (http://www.ramsar.org/cda/en/ramsar-pubs-notesanno-india/main/ramsar/1-30-

168\%5E16561_4000_0_). There are many reasons behind the designation of EKW as Ramsar site. Firstly, it is a perfect and rare example of wise use of wetland ecosystem and with a combination of environmental protection as well as development management, the treated water is utilized for agriculture and pisciculture through the recovery of nutrients in an efficient manner. City's wastewater flowing through a network of drainage canals (RSC) reach the settling ponds (Bheris) where most of the biochemical reactions are completed (including reduction of BOD) with the help of diverse microbial community utilizing solar and chemical energy. Unlike conventional mechanical wastewater treatment plants, these Bheris efficiently remove the coliforms which are prone to be pathogenic (Pradhan et al., 2008). Secondly, EKW is the largest ensemble of sewage fed fish ponds at one place in the world. It provides about 150 tons of fresh vegetables daily, about 10,500 tons of table fish per year providing livelihoods for about 50,000 people directly and many indirectly (http://www.downtoearth.org.in/Full6.asp?FolderName $=20060915 \&$ FileNAme $=$ news $\&$ sid $=3 \&$ sec_id $=$; http://www.cepis.opsoms.org/muwww/fulltext/repind53 /calcutta/calcutta.html; Chaudhuri et al., 2008a; Riley,
2011). Finally, its positional advantage and a wide variety of large habitat conditions with various resources have made it a natural incubator for the growth of huge variety of microbes. A little of its microbial diversity has been explored till now (Chaudhuri and Thakur, 2006; Ghosh et al., 2007; Adarsh et al., 2007; Roy et al., 2008; Malathu et al., 2008, Nasipuri et al., 2010, Riley, 2011; Yadav et al., 2010, Mukherjee, 2005; Thatoi, 2011; http://indiaenvironmentportal.org.in/node/34248; http://indiaenvironmentportal.org.in/node/14389). In addition to the four major ongoing activities at EKW there are various indirect benefits to the city due to its existence as has been reviewed by different groups. These include carbon sequestration, flood control, livelihood support, detoxification of the environment (solid and soluble), recreation and so on (Bhattacharyya and Santra, 2003).

Reports of urban encroachment are quite numerous and pose as a threat to the Ramsar site status of EKW. This review is an attempt to document the ongoing practices at EKW and emphasize its impact on the city in general and the country on the whole.

Geographical location and the traditional practice: EKW is a 12500 hectare area of inter-tributary mashes created by the shifting of the Hooghly River. Initially these were salt water lakes extending between the Bidyadhari River on the east and river Hooghly on the west. The former river no longer exists since almost the beginning of the last century. There have been immense changes in the land use pattern since the $18^{\text {th }}$ century mostly because of reclamation, silting of rivers and diversion of waste water (domestic as well as industrial) resulting in the marshes being stagnant and losing its connection with the Bay of Bengal. The geographical location of EKW results in its acting as a spill basin for the city of Kolkata both for rainwater storage and flood. This in turn leads to the deposition of all sorts of pollutants at EKW (Ghosh and Sen, 1987).

The integrated resource recovery at EKW dates back to mid nineteenth century with the pioneering work of Mr Bhabanath Sen. He started with acquiring one square $\mathrm{km}$ of the wetland area known as Dhapa Square Mile for for vegetable cultivation. In 1929, the first wastewater fish pond was introduced (Ghosh, 2005). However it was only in the year 1983 that the term East Calcutta Wetland was coined by Dr Dhrubajyoti Ghosh in trying to find out the fate of the city sewage and this unique asset was brought to the notice of the world (http://en.wikipedia.org/wiki/East_Kolkata_Wetlands). 
Waste Water fed fish ponds (Bheri): Waste water aquaculture dates back to late $19^{\text {th }}$ century in Munich, Germany with construction of pond complex spanning an area of 233 hectares. Similar practice was prevailing for more than couple of centuries in Asia. During 1985 in China it accounted for about $1.3 \%$ of the total freshwater fish production (Sophin, 2003). But the waste water fed aquaculture here is quite different from the above mentioned system both in architecture and preparation. The architecture and preparation of these systems have been described in details by Furedy and Ghosh (1984) and Ghosh (2005) while the science behind the practice has been explained explicitely by Chaudhuri et al. (2007) and Chaudhuri et al. (2008a). Waste water Bheri, the shallow $(50-150 \mathrm{~cm})$, flat bottom, waste water fed fish pond, found in West Bengal, India is a unique ecosystem. These water bodies have a distinct type of architecture which results in extensive purification of waste along with integrated resource recovery (Chaudhuri et al., 2008b). The traditional knowledge associated with the age old practices carried out in Bheris has a sound scientific basis. The shallow basin is responsible for full vertical circulation of water to the surface where algal growth can occur. This depth provides a better ratio between pond volume and pond surface as compared to deeper pond, thus making this architecture favourable for photosynthesis (Pradhan et al., 2008). The alkalinity due to lime addition during pond preparation results in pathogen/fecal coliform content reduction by $96-99 \%$ (Pradhan et al., 2008). One reason for the purification of sewage is the abundant quantity of algal photosynthetic oxygen generated in the pond. Bheri causes detoxification of waste water by reducing heavy metals up to $25-99 \%$ (Chattopadhyay et al., 2002), while maintaining the biological oxygen demand at above

$80 \%$

(http://www.ecotippingpoints.org/indepth/indiawetlands .html). The shallow pond allows sunlight to penetrate to its bottom and thereby helps in photosynthesis. The high alkalinity is responsible for the production of phytoplanktons, a primary product in the fish food chain. The factors favouring the purification process of water in the Bheri are the shallow depth which allow penetration of solar radiation to the bottom of the pond, the wind causing oxygenation through stirring of water, growth of multiple forms of plankton, algae and bacteria leading to active bioremediation along with the abundance of water hyacinth causing metal accumulation along the different parts of the plant (Chaudhuri et al., 2008a).

The planktonic species play a vital role in the purification process. Solar energy gets stored in a dense population of planktons which is subsequently consumed by the fishes. Planktons help to degrade the organic matter. Different planktons play specific roles in different bioremedial processes like metal accumulation, degradation of several aromatic hydrocarbons, herbicides and insecticides. A comparative study of the diversity, useful varieties and total number of planktons in rain water ponds from West Bengal, waste water fed fish ponds (called Dighi and Khamar) from Bangladesh and Bheris from West Bengal, India clearly indicated a richer diversity in case of the Bheris. The abundance of different planktons in Bheri, as compared to the Dighis, Khamars and fresh water ponds is directly correlated with the active participation of these planktons in the bioremediation process taking place in the Bheris (Pradhan et al., 2008). The excessive growth of planktons (and the associated algal bloom) is taken care of by the fishes which graze on these planktons.

The water and effluent generated from the Bheri are used for cultivation of vegetables, which, on examination using EDXRF, do not reveal any harmful metal accumulation (Chaudhuri et al., 2007). Detailed analysis of plankton varieties, plankton count, total coliform count, dissolved oxygen, conductivity of Bheri water, as compared to rain water fed ponds, Dighi as well as Khamars, clearly indicate the importance of Bheri as a facilitator for waste water purification. The superiority of the Bheris in this respect is also well established (Chaudhuri et al., 2008b). Studies also reveal the rich microbial diversity present in Bheris (Chaudhuri and Thakur, 2006).

This process is cost effective but has its own limitations like it could only be implemented in tropical countries with ambient solar energy requirement of greater than $200 \mathrm{cal} / \mathrm{cm}^{2} /$ day. The second limitation is the need for nutrient rich water to sustain photosynthetic oxygen production. In low nutrient waste water, external input addition like restaurant edible waste (stale food) is essential (Furedy and Ghosh, 1984). The net savings in cost due to fish feed comes to USD\$ 1.304 million (Ghosh, 2005). Phytoremediation is profound at EKW. Water hyacinth is associated with rhizofiltration in addition to providing shade to the fish during summer and prevention of erosion of the bank (Chaudhuri, 2008a; 2008b). Though Typha sp have been reported to be associated with phytoremediation in wetlands, there are no such reports in case of EKW. The three essential features behind the success story of Bheri are the unique architecture, the pond preparation resulting is water quality improvement and the right timing for the release of fish which prevents eutrophication but 
ensures complete utilization of the nutrients in the waste water as has been beautifully described by Ghosh (2005). In summary, Bheri appears to be a complicated ecosystem from the functional as well as biodiversity aspects and is therefore suitable for analysis as a model of a complex biological system.

Complexity analysis: Bheri can be studied as a complex biological system from qualitative as well as quantitative points of view. The former attempts to establish a correspondence between the various features of a Bheri and the characteristics of a complex system. The latter exploits power-law and scaling relationships to characterize Bheri as a complex system.

The qualitative characterization: The entire process of bioremediation and integrated resource recovery taking place in the Bheris leading to a cleaner environment and improved livelihood support is compared with the distinct features of a complex system in a point-wise manner in order to portray Bheri as a complex biological system from a qualitative viewpoint.

Bheri is made up of multiple subunits in the form of bacteria, phytoplankton, zooplankton, fish and water hyacinth. This is similar to the structure of a complex system which also consists of several subsystems.

The food chain operating in a Bheri illustrates how interaction among the different subunits of a Bheri maintains its functioning. It also clearly reveals the structure of the Bheri as spanning over several scales from microscopic bacteria to macroscopic fishes. Metal storage occurs within the submerged as well as aerial parts of water hyacinth thus reducing the metal content of water. Water draining into the Bheri is drawn from domestic household as well as industrial units and is heavily loaded with metals. This high metal content gets purified through natural processes before being released into river Hooghly (Smith et al., 2005). This phenomenon may be related to the presence of interaction among the different components of the Bheri.

The interaction among the various subunits is necessary for the completion of the processes operating within the Bheri. But no single subunit controls the process alone. Treatment of the surface with lime is required to kill the pathogens while the other microbes grow removing metals and degrading wastes. Levelling of the bottom of the pond with the specific depth ensures uniform distribution of solar radiation throughout the body of the pond which ensures phytoplankton growth. The plankton bloom is restricted by the release of the fish fry with the fish grazing on the planktons. The smaller fishes are consumed by the larger ones with the latter being food for human beings. Therefore, each subunit of the Bheri is essential for the overall functioning of the Bheri but none acts as the pivotal point. This is one of the defining features of a complex system.

The interaction among the individual components leads to several emergent properties like resource recovery, waste management, employment/economic stability and revenue generation.

Purification of soluble waste of the city takes place in the Bheris. The waste is converted to safe water for irrigation as well as fertile soil (the effluents from the bottom of the Bheri after each round of fish growth). This is responsible for providing employment to a large number of individuals (Chaudhuri et al., 2006) as well as food (vegetables, paddy and fish) to an even greater number of people. In this way, Bheris self-organize into integrated resource recovery units through their multiple functions.

The quantitative viewpoint: The process of characterizing Bheri as a complex ecosystem proceeds by utilizing the concepts of scaling and power-law relationships discussed earlier. To this end, samples were collected from five different Bheris, five different rain water ponds (both bheris and rain water ponds being situated in West Bengal, India) and three different Khamars from Dhaka, Bangladesh. The data were analyzed in terms of the saturation curves obtained and the "straight lines" fitted by the method of least squares (Mukherjee, 2005).

Microbial diversity and commercial potential: The Bheris interestingly works as both facultative as well as maturation ponds (Chaudhuri et al., 2008a) harbouring various microbes and planktons (Pradhan et al., 2008; Mukherjee, 2005). Kolkata has a hot and humid climate throughout the year due to its geographical location. Due to its climate, the area acts as a natural incubator for a diverse group of microbes. Hence it is a biodiversity rich spot. It is expected that EKW would be a rich source of bioremediants because it is the world's largest natural recycling centre for soluble and solid wastes. Since only $1-4 \%$ of the microbes of any community can be cultivated at any point of time, the objective of microbial profiling of a complex environment can be addressed only through culture independent community analysis (Amann et al., 1995). A similar approach was followed for microbial profiling of EKW where the molecular biological tools of 16SrDNA characterization through PCR amplification, cloning and sequencing were carried out. The data was further analyzed using bioinformatics 
based phylogenetic tree construction using ARB (open source software for secondary structure based phylogenetic analysis). The microbial resource mapping of this Ramsar Site indicated the presence of microorganisms from 12 different main bacterial phyla. This reflects the rich natural microbial resource at EKW (Chaudhuri and Thakur, 2006; Chaudhuri et al., 2006). The culture based study also showed a rich diversity with several varieties of anaerobic as well as aerobic microbes (Riley, 2011).

Bioinformatics based growth condition prediction and its verification through wet laboratory based trials were performed. This resulted in isolation of oil degrading, extracellular protease producing as well as metal accumulating microbes (Adarsh et al., 2007; Chowdhury et al., 2008). The variation in microbial population at different sites of EKW through culture independent analysis reveals the underlying bio remedial activity of this area. Advances in information technology based data retrieval system allowed prediction of the putative functions of the different groups of microbes indicating the possible presence of metal accumulating, oil degrading, antimicrobial compound producing as well as enzyme producing bacteria which can be exploited for commercial purposes (Chaudhuri and Thakur, 2006). The removal of metals from waste water during its journey through the wetland (Chattopadhyay et al., 2002) and the presence of metal accumulating microbes from EKW have been reported in a variety of studies (Adarsh et al., 2007; Chowdhury et al., 2008).

The high volume of automobile exhaust leads to huge load of sulphate in the megacity of Kolkata which reaches the flora and fauna of EKW through acid rain (Nasipuri et al., 2010). However, no apparent toxicity is reported in them on this account till date. This led to the search for Sulphate Reducing Bacterial (SRB) consortia from the site along with various other locations within India. As expected the best efficiency of sulphate reduction was discovered in the consortia from Bheri water at EKW grown in Medium DSMZ16695 (specific for SRB) (Chaudhuri et al., 2008b; Nasipuri et al., 2010). This site also yielded efficient nitrate reducing bacterial consortia. This particular article on EKW also emphasizes the role of bioinformatic tools in determining the microbial biodiversity, indication of their putative function in that ecosystem (through IT intervention) and prediction of the growth condition of novel microbes of commercial as well as bioremedial importance. It subsequently led to the isolation and identification of a cascade of novel important microbes/consortia (more than 1000 GenBank submissions of novel $16 \mathrm{~S}$ rDNA sequences) with potential for metal accumulation (Thatoi, 2011;
Chowdhury et al., 2011; Adarsh et al., 2007; Chowdhury et al., 2008; Riley, 2011), enzyme like protease, keratinase and lipase (Nasipuri et al., 2010; Yadav et al., 2010; Roy et al., 2008; Ghosh et al., 2007; Chowdhury et al., 2008; 2009) production as well as pollutant detoxification (sulphate, nitrate) (Nasipuri et al., 2010). The spinoff of these studies have resulted in filing of patents in the area of detergent additives (Malathu et al., 2008; Chaudhuri Novel indigenous sources of enzymes as detergent additives Indian Patent no. 599/KOL/2010 dt June 1 2010; PCT/IB2010/001816 dt July 24, 2010; U.S. Patent Application No.-13/126,109 dt $26^{\text {th }}$ April 2011) as well as enzyme mediated dehairing of hide at neutral $\mathrm{pH}$ (Chaudhuri, Hide Processing methods and Composition., Indian patent no. 863/KOL/2010 dt August 5, 2010; PCT/IB2010/002845 dt Nov 16th 2010; US patent application No-13/321,316 Dt Nov 18, 2011).

Integrated resource recovery and economic viability: EKW is the only example of wise use of wetland in India. EKW utilizes the city sewage for four traditional resource recovery practices with scientific basis. Major components include garbage farms for cultivation of vegetables, waste water fed pisciculture, paddy cultivation utilizing fish pond effluent and sewage fed brackish water aquaculture (outside EKW region). EKW contains about 272 Bheries spread over an area of 4,000 hectares. Every day 980 million litres of raw sewage is treated which is on an average about $16 \%$ of the total treated of this country per day (http://ekw-safeinch.blogspot.com/, accessed May $13^{\text {th }}$, 2009). The old dumping grounds are used for agriculture. Moreover solid waste is also used in the vegetable farms. The waste dumping ground together with the vegetable farms handles about 3,000 tons of municipal waste a day. These activities lead to the treatment of the waste generated from a city of 12 million people avoiding an expenditure of US \$22.04 million towards running expenses of a waste treatment plants. In addition the treated effluent and water is used for irrigation saving approximately USD\$ 0.56 million (Ghosh, 2005). These activities lead to the production of 13,000 tonnes of fish, 16,000 tonnes of paddy in a year and about 156 tonnes of vegetable per day (Chakraborty et al., 1987; Davis, 1993; Furedy and Ghosh, 1984; Riley, 2011). Eastern Organic Fertilizer and Excel Industries Ltd. jointly compost 700tonnes of solid waste to about 225tonnes of fertilizer that find its market in the tea gardens and the sugarcane as well as maize cultivation within India (Ranchi as well as Pune) (Bhattacharyya and Santra, 2003). Activities at EKW provides livelihood to about 80,000 wetland dwellers where the majority (84\%) fall among the underprivileged category (http://ekw- 
safeinch.blogspot.com). The economic benefit to the tune of USD \$38.54million has been reported to arise out of the traditional practices at EKW (Ghosh, 2005).

Fish cultivation ranks highest among the different resource recovery activities. Production at EKW is 2-4 times more than in rain water ponds in any other part of this country. The annual production is in the range of 4,000 tons (Ghosh, 2005; http://www.asienhaus.de/pblic/archive/chap5.pdf) to 13,000 tons while the annual consumption of the city is 50,000 tons (Riley, 2011). This explains the substantial food production. The low cost of edibles in the city is to a major extent due to low transportation cost due to location of EKW within the city (Riley, 2011).

EKW: Controversies and contaminations: Some issues pertaining to EKW have led to concern among the people of Kolkata. These issues can be broadly divided into three categories.

Fish production: The role of EKW is like that of a natural sewage treatment plant for the city of Kolkata with wastes of the entire city being dumped here. These wastes are sometimes contaminated with toxic metals. There is, therefore, a probability that these toxic metals get accumulated in the fish which reside in these water bodies. Doubts also arise concerning the edibility of these fishes from the standpoint of faecal microbial contamination. There are some reports in the literature regarding accumulation of heavy metals in different organs of the fish cultivated at EKW (Bhattacharyya and Santra, 2003; Chakraborty et al., 1987; Santra and Bano, 1998; Ghosh, 1999). Reports also point towards the bacterial and viral contamination of the fish grown at EKW arising from their origin (Bhattacharyya and Santra, 2003).

The observed decrease in the coliform count of up to $99 \%$ in the Bheris as compared to other fresh water ponds and waste water fed fish ponds from the neighbouring country of Bangladesh (locally called Khamar) rules out the possibility of severe pathogenic contamination in the fishes due to sewage cultivation. A much healthier picture of the Bheris is provided by the quantitative as well as qualitative analysis of Planktons (an indicator of water quality) in comparison to rain water ponds and Khamars (Pradhan et al., 2008). The threat of bacterial contamination is even more decreased due to the fact that fish is not consumed in raw form in Bengal (Davis, 1993).

Energy Dispersive X Ray Fluorescence Analysis was implemented using water along with the soil from Bheri and its corresponding raw sewage canal (this is the source from where the liquid waste gets drained into the Bheri) to test for the presence of heavy metals
(Chaudhuri et al., 2008a). EKW produces healthy looking fish, tasting similar to those obtained from other sites. The afore-mentioned observation led to the investigation of fish muscles from a surface feeder Labeo rohita and a bottom-grazer, Cirrhinus mrigala using the non destructive and sensitive tool of EDXRF for both EKW and non-EKW (i.e fresh water pond) grown fishes. The data did not show any significant difference in the extent of metal accumulation between the two specimens. However, upon comparing the accumulation in the fishes with the WHO recommended standards, metals like Chromium, Copper, Rubidium and Lead were found to have higher accumulation from both the sites. Besides, Lead was detected to be higher in non-EKW compared to EKW grown fishes. This could be a result of the existence of the small cottage factories in the vicinity of the fresh water ponds in the suburbs of Kolkata. The accumulation of metals in fishes from EKW as well as non-EKW sites point towards the diverse microscopic population and some other geochemical factors responsible for the phenomenon of sedimentation and biomagnification of metals in the fish pond and their subsequent uptake in the aquatic food chain (Chaudhuri et al., 2008a; 2008b).

Vegetable production: Historically waste recycling took place at EKW through vegetable farming. This technique utilizes the vegetable farms and paddy fields that sustain on the garbage and effluent emanating from the waste water fed fisheries as manure and water for irrigation. Cultivable lands have been formed out of the old solid waste dumping grounds. 150 tonnes of fresh vegetables are produced daily by the garbage farms (Ghosh, 2005). The paddy fields generate 16,000 tonnes of winter paddy varieties cultivated during post monsoon period annually (Ghosh, 2005). There is a fair amount of controversy and obscurity surrounding the safety, quality and reliability of the farming procedure using the treated solid as well as soluble waste for cultivation of green leafy vegetables at EKW (Bhattacharyya and Santra, 2003; Gupta et al., 1990).

The healthy look of the product corroborates its quality. The procedure followed for production is a time tested one guaranteeing its reliability. It is the issue of safety that is the principal matter of concern. An EDXRF based analysis was carried out to study different elements in green leafy vegetables like Amaranthus caudatus, Amaranthus blithum and Spinacia oleracea from EKW sites as well as distant places (non-EKW sites) (Chaudhuri et al., 2007). No adverse accumulation was observed and the net consumption of the above-mentioned elements per 
person per day was calculated and found to be much below the Recommended Dietary Allowance (RDA) levels in all cases. The detoxification process occurring at $\mathrm{EKW}$ is powered by natural mechanisms free from any type of chemical treatment. Hence, the process of cultivation is not at all affected by the hazardous effects of chemicals fertilizers. The above discussion clearly indicates that the vegetables grown out of integrated resource recovery mechanism at EKW are safe for human consumption. This is further confirmed by the healthy appearance of these vegetables (Chaudhuri et al., 2007). No documented evidence exists, so far, of Kolkata's population having been affected by the consumption of fish and vegetables grown on the treated wastewaters (http://www.asienhaus.de/pblic/archive/chap5.pdf; Chaudhuri et al., 2007; 2008a).

Occupational hazard: Scattered reports exist regarding the health risk that the workers as well as people of surrounding areas of EKW are exposed to (Bhattacharyya and Santra, 2003). However, it appears that most of the pathologies reported, like round worm ova in stool, Urinary tract infection, Genital ulcer, Diarrhoea, Jaundice are largely due to sanitary practices rather than EKW habitat. Though this practice is a little over 100 years old now, no major epidemic outbreak has yet been reported. This points to the fact that occupational hazard at EKW possibly poses little health risk (Chaudhuri et al., 2008b).

Land encroachment: Frequent reports of land encroachment at EKW due to urban encroachment have triggered a debate regarding EKW losing its international recognition of being a Ramsar site-a wetland of international importance. Decrease in the area of EKW would lead to detrimental consequences like changes in ecosystem qualities (flora and fauna), loss of livelihood as well as revenue resulting from a reduced wetland area. The cumulative effect would be a disaster for the city of Kolkata. Overtly, different steps have been initiated for the conservation of EKW. The state Government formulated a strategy for evicting the 25,000 odd encroachers of the wetland. According to environment officials these people were lodged in hutments spanning an area of 10000 acres. The government wanted to resettle them in the same area but in a planned manner and also train them for self employment under the East Kolkata Wetland Development Project. This was supposed to be executed with financial assistance from international organizations as reported by Telegraph on December 21st, 2005 ('Evict-rehabilitate plan for wetlands', http://www.telegraphindia.com/archives/archive.html). As per Kolkata Newsline of March 11, 2006, the government of West Bengal has passed the East Kolkata Wetland Management and Conservation Bill 2006

(http://cities.expressindia.com/fullstory.php?newsid=17 3284). According to this Bill, anyone convicted to be guilty of altering the nature of the wetland would be fined an amount of approximately USD\$ 2000 along with 3 years of imprisonment.

Future prospect: The foregoing study is a clear pointer towards the importance of wetland as integrated resource recovery ecosystems. It is a multifaceted treasure that needs to be preserved with great dedication. It was a traditional knowledge that was passed across generations for nearly 100 years. Initiatives were taken by some groups of scientists to understand and also document the mechanism operating there. One of the major previous compilations in this domain came out in 2005 by Dr Dhrubajyoti Ghosh, a pioneer in the area (Ghosh, 2005) and one of the authors of this review article. Future application of this knowledge would entail technology transfer to other areas having similar topography and climatic conditions. One such attempt has been initiated jointly by West Bengal University of Technology (WBUT), Kolkata, India and Environment \& Population Research Centre (EPRC), Dhaka, Bangladesh as an outcome of the collaborative research (Pradhan et al., 2008) under the stewardship of the then Vice Chancellor of WBUT, Prof A R Thakur, another author of this article.

The rich biodiversity of the East Kolkata Wetland holds tremendous promises for far-reaching applications in bioremediation and commercial utilization. In order to effectively use the microbial resource of the wetland for the above mentioned purpose, isolation of different bacterial strains was carried out from different sites of EKW.

\section{CONCLUSION}

East Kolkata Wetlands in general and Bheris in particular can be considered as excellent examples of integrated resource recovery systems utilizing traditional knowhow for the benefit of environment as well as society. This wetland is of paramount importance for maintaining of ecological balance and environmental sustainability. It also provides employment and food resource along with treating the waste for the 12 million inhabitants of the city of Kolkata. Apart from environmental protection and economy generation it holds tremendous potential for the fledgling biotechnology industry in West Bengal 
and also in India. This study reflects the pressing need for further documentation of traditional practices being undertaken at EKW to ensure its conservation as well as for possibility of replication at other sites.

\section{ACKNOWLEDGEMENT}

The researchers would like to acknowledge all the authors of the papers mentioned in the reference for their efforts for documenting their work. The authors would like to thank the granting agencies like, Department of Biotechnology, GOI; Department of Science and Technology, GOI; Board of Research in Nuclear Sciences, GOI; University Grants Commission (under UGC-DAE and IUAC funding), GOI; Indian Council for Agricultural Research, GOI and West Bengal Pollution Control Board for their financial Assistance. They would like to thank West Bengal University of Technology for the laboratory and computational facility.

\section{REFERENCES}

Adarsh, V.K., M. Mishra, S. Chowdhury, M. Sudarshan and A.R. Thakur et al., 2007. Studies on metal microbe interaction of three bacterial isolates from East Calcutta Wetland. Online J. Biol. Sci., 7: 8088. DOI: $10.3844 /$ ojbsci.2007.80.88

Amann, R.I., W. Ludwig and K.H. Schleifer, 1995. Phylogenetic identification and in situ detection of individual microbial cells without cultivation. Microbial. Rev., 59: 143-169.

Bhattacharyya, S. and S.C. Santra, 2003. Environmental Status of East Calcutta Wetlands and Strategies for Sustainable Management. In: Ecology, Economy and Society, Khasnabis, R. (Ed.). University of Calcutta. Kolkata, India, pp: 65-94.

Chakraborty, D., D. Ghosh and S. Niyogi, 1987. Calcutta pollutants: Part 1: Appraisal of some heavy metals in Calcutta City sewage and sludge in use for fisheries and agriculture. Int. J. Environ. Anal. Chem., 30: 243-253. DOI: 10.1080/03067318708075473

Chattopadhyay, B., A. Chatterjee and S.K. Mukhopadhyay, 2002. Bioaccumulation of metals in the East Calcutta Wetland Ecosystem. Aquatic Ecosyst. Health Manage., 5: 191-203. DOI: 10.1080/14634980290031848

Chaudhuri, S.R., A.K. Pattanayak and A.R. Thakur, 2006. Microbial DNA extraction from samples of varied origin. Curr. Sci., 91: 1697-1700.

Chaudhuri, S.R. and A.R. Thakur, 2006. Microbial genetic resource mapping of East Calcutta Wetlands. Curr. Sci., 91: 212-217.
Chaudhuri, S.R., 2008a. East Calcutta Wetland: A multifaceted treasure to be preserved. Proceedings of the International Conference on Environmental Research and Technology (ICERT'08). Parkoyal Penang, Malaysia.

Chaudhuri, S.R., 2008b. EDXRF as a tool for characterizing Microbes with potential for bioremediation. Proceedings of the National Workshop On Trace Elements Research. Shillong. India.

Chaudhuri, S.R., S. Salodkar, M. Sudarshan and A.R. Thakur, 2007. Integrated resource recovery at east Calcutta wetland-how safe is these? Am. J. Agric. Biol. Sci., 2: 75-80. DOI: 10.3844/ajabssp.2007.75.80

Chaudhuri, S.R., M. Mishra, S. Salodkar, M. Sudarshan and A.R. Thakur, 2008a. Traditional aquaculture practice at east Calcutta Wetland: The safety assessment. Am. J. Environ. Sci., 4: 140-144. DOI: 10.3844/ajessp.2008.140.144

Chaudhuri, S.R., S. Salodkar, M. Sudarshan, I. Mukherjee and A.R. Thakur, 2008b. Role of water hyacinth-mediated phytoremediation in waste water purification at east Calcutta wetland. Environ. Sci., 5: 53-62. DOI: 10.1080/15693430701833427

Chowdhury, S., A. Chakraborty, A.R. Thakur and S.R. Chaudhuri, 2009. Radiation induced DNA double strand break studies of a metal sensitive novel bacterial isolate from East Calcutta Wetland. Am. J. Environ. Sci., 5: 398-405. DOI: 10.3844/ajessp.2009.398.405

Chowdhury, S., A.R. Thakur and S.R. Chaudhuri, 2011. Novel microbial consortium for laboratory scale lead removal from city effluent. J. Environ. Sci. Technol., 4: 41-54.

Chowdhury, S., M. Mishra, V.K. Adarsh, A. Mukherjee and A.R. Thakur et al., 2008. Novel metal accumulator and protease secretor microbes from East Calcutta Wetland. Am. J. Biochem. Biotechnol., 4: 255-264. DOI: 10.3844/ajbbsp.2008.255

Davis, T.J., 1993. Towards the Wise use of Wetlands: Report of the Ramsar Convention Wise Use Project. 1st Edn., Ramsar Convention Bureau, Gland, Switzerland, ISBN-10: 2940073074, pp: 180.

Furedy, C. and D. Ghosh, 1984. Resource-conserving traditions and waste disposal: The garbage farms and sewage-fed fisheries of Calcutta. Conservat. Recycl., 7: 159-165. DOI: 10.1016/03613658(84)90014-6 
Ghosh, A., B. Maity, K. Chakrabarti and D. Chattopadhyay, 2007. Bacterial diversity of East Calcutta Wet Land area: Possible identification of potential bacterial population for different biotechnological uses. Microbial. Ecol., 54: 452459. DOI: 10.1007/s00248-007-9244-Z

Ghosh, D. and S. Sen, 1987. Ecological History of Calcutta's Wetland Conversion. Environ. Conserv., 14: 219-226. DOI: 10.1017/s0376892900016416

Ghosh, D., 1999. Participatory management in wastewater treatment and reuse in West Bengal. UWEP Occasional.

Ghosh, D., 2005. Ecology and Traditional Wetland Practice: Lessons from Wastewater Utilisation in the East Calcutta Wetlands. 1st Edn., Worldview, Kolkata, pp: 120.

Gupta, S.K., A. Mitra and S. Adhikari, 1990. Post irrigation effect of Calcutta sewage effluents on soil and vegetations. Proceedings of National Symposium on Protection of Environment of City Water Fronts, (PECWF' 90), Central Water Commission, New Delhi, pp: 7-13.

Malathu, R., S. Chowdhury, M. Mishra, S. Das and P. Moharana et al., 2008. Characterization and wash performance analysis of microbial extracellular enzymes from East Calcutta Wetland in India. Am. J. Applied Sci., 5: 1650-1661. DOI: 10.3844/ajassp.2008.1650.1661

Mukherjee, S., 2005. Evict- Evict-rehabilitate plan for wetlands plan for wetlands.

Nasipuri, P., G.G. Pandit, A.R. Thakur and S.R. Chaudhuri, 2010. Comparative study of soluble sulfate reduction by bacterial consortia from varied regions of India. Am. J. Environ. Sci., 6: 152-158. DOI: 10.3844/ajessp.2010.152.158
Pradhan, A., P. Bhaumik, S. Das, M. Mishra and S. Khanam et al., 2008. Phytoplankton diversity as indicator of water quality for fish cultivation. Am. J. Environ. Sci., 4: 406-411. DOI: 10.3844/ajessp.2008.406.411

Riley, A.T., 2011. Advances in Environmental Research. 1st Edn., Nova Science Pub Incorporated, Hauppauge, New York, ISBN-10: 1608761681, pp: 373.

Roy, S., A.N. Ghosh and A.R. Thakur, 2008. Uptake of $\mathrm{Pb}^{2+}$ by a cyanobacterium belonging to the genus Synechocystis, isolated from East Kolkata Wetlands. Biometals, 21: 515-524. DOI: 10.1007/s10534-008-9138-7

Santra, S.C. and N. Bano, 1998. Heavy metal accumulation in fish: An assessment in sewage fed aquafarm of east Calcutta, India. Proceeding of the National Seminar on Environment Biology, Apr. 35, Visva-Bharati University, Santiniketan, India, pp: 35-38.

Smith, V.H., B.L. Foster, J.P. Grover, R.D. Holt and M.A. Leibold et al., 2005. Phytoplankton species richness scales consistently from laboratory microcosms to the world's oceans, PNAS, 102: 4393-4396. DOI: 10.1073/pnas.0500094102

Sophin, P., 2003. Waste recycling and fish culture literature review. Prek Leap Agricultural College.

Thatoi, H.N., 2011. Microbial Biotechnology: Methods and Applications. 1st Edn., Alpha Science Int'1 Ltd, ISBN-10: 1842657240, pp: 336.

Yadav, J., S. Chowdhury and S.R. Chaudhuri, 2010. Purification and characterization of an extracellular protease from Pseudomonas aeruginosa Isolated from East Calcutta Wetland. J. Biol. Sci., 10: 424431. 